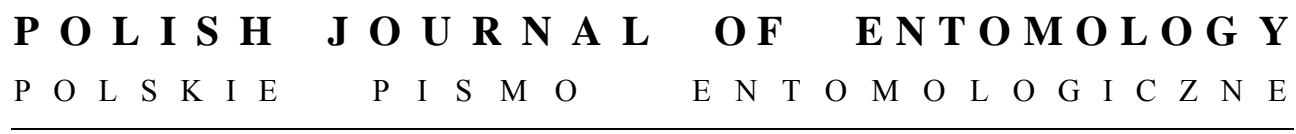

VOL. 81: 107-118

Gdańsk

30 June 2012

DOI: $10.2478 / \mathrm{v} 10200-011-0070-8$

\title{
The structure of the male reproductive system of the genus Psallus FIEBER (Hemiptera: Heteroptera: Miridae)
}

\author{
EWA MRÓZ \\ Department of Zoology, University of Silesia, Bankowa 9, 40-007 Katowice, Poland, \\ e-mail: ewa.mroz@us.edu.pl
}

\begin{abstract}
The paper presents information on the structure of the male reproductive system in representatives of six subgenera of the genus Psallus. The research demonstrated that the morphological layout of this system is much the same in all the species examined. There are no differences at the subgeneric level.
\end{abstract}

KEY WORDS: true bug, male reproductive system, taxonomy, comparative anatomy.

\section{INTRODUCTION}

The genus Psallus was established by FIEBER (1858) and so far includes around 150 species (KERZHNER \& JOSIFOV 1999, YASUNAGA \& ViNOKUROV 2000).

In Poland 20 species have been identified (GorCZYCA 2007). The species belonging to the genus Psallus are traditionally classified into six subgenera (Apocremnus FIEBER, Hylopsallus Wagner, Mesopsallus Wagner, Phylidea Reuter, Pityopsallus Wagner and Psallus FIEBER), distinguished on the basis of the morphological differences between their representatives. The features distinguishing particular subgenera are the following: the different length of particular metatarsal segments, the colouring of the hairs covering the body, the colour of some segments of the antennae and legs. The subgenera also differ in the structure of the male genitalia, but no clear scheme can be established. The taxonomy of these subgenera used to be a subject of much dispute, and there are still a few species in the genus Psallus with an unclear subgeneric position (KERZHNER \& JOSIFOV 1999). There are many examples of sibling species in the genus Psallus; only the males of these are distinguishable, however, on the basis of the aedeagus. 
Representatives of the subgenus Pityopsallus feed on coniferous trees and are often encountered in the boreal and mountainous parts of the Palaearctic (VINOKUROV 1998). The representatives of the other subgenera are ecologically associated mostly with deciduous trees and bushes.

The comparative anatomy of true bugs has been the subject of numerous papers, which have made a valuable contribution to modern taxonomic analyses (KULLENBERG 1947, Carayon 1950, Woodward 1950, Pendergrast 1957, Leston 1961, Kumar 1967, Malipatil 1978, AkingbohungBe 1983, GrozeVa \& Kuznetsova 1992, Mróz 2007, MRÓZ \& WOJCIECHOWSKI 2011).

Research based on the features of reproductive system morphology useful for taxonomic analyses has been conducted in Heteroptera by PENDERGRAST (1957), LESTON (1961), Akingbohungbe (1983), Grozeva \& Kuznetsova (1992), Mróz (2007) and MRÓZ \& WOJCIECHOWSKI (2011). These studies have shown that, on the basis of reproductive system morphology, some evolutionary tendencies within individual phylogenetic lineages of Heteroptera can be perceived. The number and arrangement of follicles, as well as the number, origin and structure of accessory glands are the features most commonly taken into consideration. However, this kind of anatomical research has not been carried out in order to solve the taxonomic status of subgenera and evolutionary tendencies within the genus Psallus.

The aim of this research was to determine whether, on the basis of an examination of anatomical structures, it would be possible to re-evaluate the relationships within the genus Psallus. For this purpose the structures of the male reproductive system were thoroughly analysed.

\section{Acknowledgements}

I am grateful to Dr Dominik Chłond for his help with the collection and identification of the material. I would also like to thank Prof. Jacek Gorczyca for his valuable suggestions regarding this article.

\section{MATERIALS AND METHODS}

Male individuals of eight species, representatives of all six subgenera in the genus Psallus, were analysed.

\section{Material examined}

\section{Apocremnus:}

P. (A.) betuleti (FAlléN, 1807) - Sosnowiec-Zagórze, 29.05.2006, 3 males, SosnowiecŚrodula, 14.06.2007, 3 males, 10.06. 2009, 4 males, leg. E. Mróz. Collected from Betula sp. 


\section{Hylopsallus:}

P. (H.) perrisi (MulsanT et REY, 1852) - Dąbrowa Górnicza - Park Zielona, 2.06.2005, 3 males, 20.05.2006, 3 males, 10.06.2006, 3 males, leg. D. Chłond and E. Mróz. Collected from Quercus sp.

P. (H.) wagneri (OssianniLsson, 1953) - Dąbrowa Górnicza - Park Zielona, 10.06.2006, 2 males, leg. D. Chłond and E. Mróz. Collected from Quercus sp.

P. (H.) variabilis (FALLÉN, 1807) - Dąbrowa Górnicza - Park Zielona, 2.06.2005, 4 males, leg. D. Chłond and E. Mróz, Ojców National Park, 14.06.2005, 2 males, leg. D. Chłond, Sosnowiec-Zagórze, 14.06.2006 (5), leg. E. Mróz. Collected from Quercus sp.

\section{Mesopsallus:}

P. (M.) ambiguus (FALlén, 1807) - Dąbrowa Górnicza - Park Zielona, 2.06.2005, 2 males, 3.07.2009, 2 males, leg. D. Chłond and E. Mróz, Ojców National Park, 14.06.2005, 1 males, 27.06.2006, 3 males, leg. D. Chłond. Collected from Alnus incana $\mathrm{MOENCH}$

\section{Phylidea:}

P. (Ph.) quercus (KIRSCHBAUM, 1856) - Dąbrowa Górnicza - Park Zielona, 2.06.2005, 2 males, leg. D. Chłond and E. Mróz. Collected from Quercus robur L.

\section{Pityopsallus:}

P. (P.) vittatus ReUTER, 1883 - Sosnowiec-Zagórze, 3.08.2006, 2 males, 15.08.2007, 3 males, leg. E. Mróz, Zakopane - Kościelisko 2.07.2007, 3 males, leg. E. Mróz, Katowice - Park Kościuszki 29.08.2009, 1 males, leg. D. Chłond and E. Mróz. Collected from Larix decidua MILL.

\section{Psallus:}

P. (P.) falleni REUTER, 1883 - Sosnowiec-Środula 29.07.2006, 4 males, 14.06.2007, 5 males, and 10.06. 2009, 4 males, leg. E. Mróz. Collected from Betula sp.

The entire male reproductive system of each of these specimens were mounted in a drop of glycerine; in addition, histological slides were prepared for 5 species: (P. (M.) ambiguus (FAllÉN, 1807), P. (H.) variabilis (FAlléN, 1807), P. (P.) falleni REUTER, 1883, P. (A.) betuleti (FALLÉN, 1807), P. (P.) vittatus REUTER, 1883).

In order to facilitate the anatomical analysis, the material was preserved in Carnoy liquid (glacial acetic acid + absolute alcohol) for 20-30 minutes and then transferred to $70 \%$ ethyl alcohol. Together with standard histological methods, the paraffin method was used to prepare the specimens. These were stained using Erlich acid haematoxylin, oxygenated under running water and differentiated with $0.5 \%$ xylidine ponceau (in 1\% acetic acid) (BAGIŃSKI 1969).

Flat reconstructions (cross-sections) of the reproductive system were prepared from the microscopic slides. Longitudinal sections and total specimens of the male reproductive system of the species were also prepared.

Digital images were obtained with a DN-100 camera installed in a Nikon Eclipse-E600 
light microscope. The measurements were performed using Lucia net software, and the drawings of the male reproductive system were made with the aid of an Olympus SZX9 stereo microscope with a $7 \mathrm{x}$ zoom.

\section{RESULTS}

The anatomical analysis showed that the structure of the male reproductive system in all the species of the genus under study represented a common scheme. The measurements of the various structures are listed in the Table.

Table. Measurements of the male reproductive system structures in some species of Psallus (all values in $\mathrm{mm}$ ).

\begin{tabular}{|c|c|c|c|c|c|c|c|c|c|}
\hline & & $\begin{array}{l}P . \\
\text { betuleti }\end{array}$ & $\begin{array}{l}P . \\
\text { variabilis }\end{array}$ & $\begin{array}{l}P . \\
\text { perrisi }\end{array}$ & $\begin{array}{l}P . \\
\text { wagneri }\end{array}$ & $\begin{array}{l}P . \\
\text { ambiguus }\end{array}$ & $\begin{array}{l}P . \\
\text { quercus }\end{array}$ & $\begin{array}{l}P . \\
\text { vittatus }\end{array}$ & $\begin{array}{l}P . \\
\text { falleni }\end{array}$ \\
\hline \multirow{3}{*}{$\begin{array}{l}\stackrel{n}{0} \\
\stackrel{0}{0}\end{array}$} & $\begin{array}{l}\text { Length of } \\
\text { testis }\end{array}$ & $\begin{array}{c}0.48- \\
0.68\end{array}$ & $\begin{array}{c}0.44- \\
0.63\end{array}$ & $\begin{array}{c}0.45- \\
0.58\end{array}$ & $\begin{array}{c}0.45- \\
0.52\end{array}$ & $\begin{array}{c}0.47- \\
0.64\end{array}$ & $\begin{array}{c}0.42- \\
0.46\end{array}$ & $\begin{array}{c}0.4- \\
0.6\end{array}$ & $\begin{array}{c}0.45- \\
0.58\end{array}$ \\
\hline & $\begin{array}{l}\text { Width of } \\
\text { testis }\end{array}$ & $\begin{array}{l}0.3- \\
0.45\end{array}$ & $\begin{array}{c}0.28- \\
0.42\end{array}$ & $\begin{array}{c}0.29- \\
0.39 \\
\end{array}$ & $\begin{array}{c}0.28- \\
0.36 \\
\end{array}$ & $\begin{array}{l}0.3- \\
0.46 \\
\end{array}$ & $\begin{array}{c}0.27- \\
0.38\end{array}$ & $\begin{array}{c}0.27- \\
0.39\end{array}$ & $\begin{array}{c}0.28- \\
0.4\end{array}$ \\
\hline & $\begin{array}{l}\text { Diameter of } \\
\text { testicular } \\
\text { follicles }\end{array}$ & $\begin{array}{c}0.12- \\
0.14\end{array}$ & $\begin{array}{c}0.12- \\
0.14\end{array}$ & $\begin{array}{c}0.12- \\
0.13\end{array}$ & $\begin{array}{c}0.12- \\
0.13\end{array}$ & $\begin{array}{l}0.1- \\
0.13\end{array}$ & $\begin{array}{l}0.1- \\
0.12\end{array}$ & $\begin{array}{c}0.11- \\
0.12\end{array}$ & $\begin{array}{c}0.09- \\
0.11\end{array}$ \\
\hline \multirow{4}{*}{ 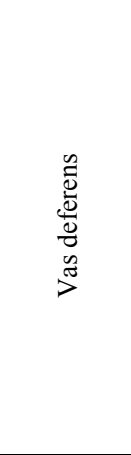 } & $\begin{array}{l}\text { Length of } \\
\text { vas deferens }\end{array}$ & $\begin{array}{c}0.7- \\
0.8\end{array}$ & $\begin{array}{c}0.6- \\
0.7\end{array}$ & $\begin{array}{c}0.59- \\
0.7\end{array}$ & $\begin{array}{l}0.6- \\
0.68\end{array}$ & $\begin{array}{l}0.6- \\
0.71\end{array}$ & $\begin{array}{c}0.6- \\
0.7\end{array}$ & $\begin{array}{c}0.58- \\
0.7\end{array}$ & $\begin{array}{c}0.6- \\
0.7\end{array}$ \\
\hline & $\begin{array}{l}\text { Width of } \\
\text { vas deferens }\end{array}$ & $\sim 0.03$ & $\sim 0.03$ & $\sim 0.03$ & $\sim 0.03$ & $\sim 0.03$ & $\sim 0.03$ & $\sim 0.03$ & $\begin{array}{c}\sim \\
0.025 \\
\end{array}$ \\
\hline & $\begin{array}{l}\text { Diameter of } \\
\text { seminal } \\
\text { vesicles }\end{array}$ & $\begin{array}{c}0.07- \\
0.08\end{array}$ & 0.07 & $\begin{array}{c}0.06- \\
0.07\end{array}$ & $\begin{array}{c}0.06- \\
0.07\end{array}$ & $\begin{array}{c}0.06- \\
0.07\end{array}$ & 0.07 & $\begin{array}{c}0.06- \\
0.07\end{array}$ & $\begin{array}{c}0.05- \\
0.7\end{array}$ \\
\hline & $\begin{array}{l}\text { Diameter of } \\
\text { common } \\
\text { vas deferens }\end{array}$ & $\begin{array}{c}0.07- \\
0.09\end{array}$ & $\begin{array}{c}0.07- \\
0.09\end{array}$ & $\begin{array}{c}0.07- \\
0.09\end{array}$ & $\begin{array}{c}0.07- \\
0.09\end{array}$ & $\begin{array}{c}0.07- \\
0.09\end{array}$ & $\begin{array}{c}0.07- \\
0.08\end{array}$ & $\begin{array}{c}0.07- \\
0.09\end{array}$ & $\begin{array}{c}0.07- \\
0.09\end{array}$ \\
\hline \multirow{2}{*}{ 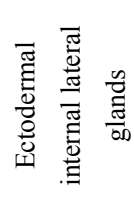 } & Total length & $\begin{array}{l}1.5- \\
1.85\end{array}$ & $\begin{array}{c}1.16- \\
1.6\end{array}$ & $\begin{array}{c}1.4- \\
1.7\end{array}$ & $\begin{array}{l}1.2- \\
1.43\end{array}$ & $\begin{array}{l}1.3- \\
1.68\end{array}$ & $\begin{array}{c}1.32- \\
1.41\end{array}$ & $\begin{array}{c}1.1- \\
1.6\end{array}$ & $\begin{array}{l}1.2- \\
1.52\end{array}$ \\
\hline & $\begin{array}{l}\text { Length of } \\
\text { ascending } \\
\text { arm }\end{array}$ & $\begin{array}{c}1.15- \\
1.4\end{array}$ & $\begin{array}{c}0.96- \\
1.3\end{array}$ & $\begin{array}{c}1.13- \\
1.32\end{array}$ & $\begin{array}{c}0.95- \\
1.1\end{array}$ & $\begin{array}{c}1.03- \\
1.35\end{array}$ & $\begin{array}{l}1.1- \\
1.15\end{array}$ & $\begin{array}{l}0.8- \\
1.22\end{array}$ & $\begin{array}{l}0.9- \\
1.32\end{array}$ \\
\hline
\end{tabular}




\begin{tabular}{|c|c|c|c|c|c|c|c|c|c|}
\hline & $\begin{array}{l}\text { Width of } \\
\text { narrow part } \\
\text { of } \\
\text { ascending } \\
\text { arm }\end{array}$ & $\begin{array}{c}0.06- \\
0.08\end{array}$ & $\begin{array}{c}0.05- \\
0.07\end{array}$ & $\begin{array}{c}0.05- \\
0.06\end{array}$ & 0.05 & $\begin{array}{c}0.05- \\
0.07\end{array}$ & 0.06 & $\begin{array}{c}0.05- \\
0.06\end{array}$ & $\begin{array}{c}0.05- \\
0.07\end{array}$ \\
\hline & $\begin{array}{l}\text { Length of } \\
\text { expanded } \\
\text { part of } \\
\text { ascending } \\
\text { arm }\end{array}$ & $\begin{array}{c}0.37- \\
0.5\end{array}$ & $\begin{array}{c}0.29- \\
0.4\end{array}$ & $\begin{array}{c}0.3- \\
0.4\end{array}$ & $\begin{array}{c}0.27- \\
032\end{array}$ & $\begin{array}{c}0.32- \\
0.42\end{array}$ & $\begin{array}{c}0.33- \\
0.35\end{array}$ & $\begin{array}{l}0.3- \\
0.33\end{array}$ & $\begin{array}{c}0.28- \\
0.41\end{array}$ \\
\hline & $\begin{array}{l}\text { Width of } \\
\text { expanded } \\
\text { part of } \\
\text { ascending } \\
\text { arm }\end{array}$ & $\begin{array}{c}0.09- \\
0.12\end{array}$ & $\begin{array}{c}0.08- \\
0.1\end{array}$ & $\begin{array}{c}0.09- \\
0.1\end{array}$ & $\begin{array}{c}0.07- \\
0.08\end{array}$ & $\begin{array}{c}0.08- \\
0.11\end{array}$ & $\begin{array}{c}0.09- \\
0.1\end{array}$ & $\begin{array}{c}0.08- \\
0.09\end{array}$ & $\begin{array}{c}0.09- \\
0.1\end{array}$ \\
\hline & $\begin{array}{l}\text { Length of } \\
\text { expanded } \\
\text { part of } \\
\text { descending } \\
\text { arm }\end{array}$ & $\begin{array}{c}0.3- \\
0.4\end{array}$ & $\begin{array}{c}0.2- \\
0.3\end{array}$ & $\begin{array}{c}0.23- \\
0.34\end{array}$ & $\begin{array}{l}0.2- \\
0.24\end{array}$ & $\begin{array}{c}0.23- \\
0.3\end{array}$ & $\begin{array}{c}0.22- \\
0.25\end{array}$ & $\begin{array}{c}0.27- \\
0.35\end{array}$ & $\begin{array}{c}0.19- \\
0.28\end{array}$ \\
\hline & $\begin{array}{l}\text { Width of } \\
\text { expanded } \\
\text { part of } \\
\text { descending } \\
\text { arm }\end{array}$ & $\begin{array}{c}0.05- \\
0.65\end{array}$ & $\begin{array}{c}0.04- \\
0.06\end{array}$ & $\begin{array}{c}0.03- \\
0.05\end{array}$ & $\begin{array}{l}0.2- \\
0.25\end{array}$ & $\begin{array}{r}0.04- \\
0.06\end{array}$ & 0.05 & $\begin{array}{c}0.05- \\
0.06\end{array}$ & $\begin{array}{c}0.05- \\
0.06\end{array}$ \\
\hline \multirow{5}{*}{ 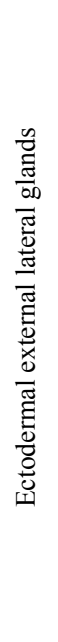 } & Total length & $\begin{array}{c}1.8- \\
2.6\end{array}$ & $\begin{array}{l}1.5- \\
2.32\end{array}$ & $\begin{array}{c}1.71- \\
2.06\end{array}$ & $\begin{array}{c}1.65- \\
1.8\end{array}$ & $\begin{array}{c}1,8- \\
2.4\end{array}$ & $\begin{array}{c}1.86- \\
2.16\end{array}$ & $\begin{array}{c}1.4- \\
2.1\end{array}$ & $\begin{array}{c}1.4- \\
2.4\end{array}$ \\
\hline & $\begin{array}{l}\text { Length of } \\
\text { ascending } \\
\text { arm }\end{array}$ & $\begin{array}{c}1.05- \\
1.03\end{array}$ & $\begin{array}{l}0.8- \\
1.24\end{array}$ & $\begin{array}{c}1.01- \\
1.19\end{array}$ & $\begin{array}{l}0.9- \\
1.05\end{array}$ & $\begin{array}{c}0.96- \\
1.3\end{array}$ & $\begin{array}{c}1.03- \\
1.01\end{array}$ & $\begin{array}{c}0.75- \\
1.18\end{array}$ & $\begin{array}{l}0.7- \\
1.13\end{array}$ \\
\hline & $\begin{array}{l}\text { Width of } \\
\text { ascending } \\
\text { arm }\end{array}$ & $\begin{array}{c}0.14- \\
0.18\end{array}$ & $\begin{array}{c}0.12- \\
0.15\end{array}$ & $\begin{array}{c}0.13- \\
0.15\end{array}$ & $\begin{array}{c}0.11- \\
0.12\end{array}$ & $\begin{array}{c}0.12- \\
0.16\end{array}$ & $\begin{array}{c}0.14- \\
0.15\end{array}$ & $\begin{array}{c}0.12- \\
0.14\end{array}$ & $\begin{array}{c}0.13- \\
0.15\end{array}$ \\
\hline & $\begin{array}{l}\text { Length of } \\
\text { descending } \\
\text { arm }\end{array}$ & $\begin{array}{l}0.8- \\
0.98\end{array}$ & $\begin{array}{c}0.6- \\
0.9\end{array}$ & $\begin{array}{c}0.68- \\
0.8\end{array}$ & $\begin{array}{c}0.67- \\
0.73\end{array}$ & $\begin{array}{c}0.68- \\
0.9\end{array}$ & $\begin{array}{c}0.69- \\
0.75\end{array}$ & $\begin{array}{c}0.53- \\
0.76\end{array}$ & $\begin{array}{c}0.55- \\
0.96\end{array}$ \\
\hline & $\begin{array}{l}\text { Width of } \\
\text { descending } \\
\text { arm }\end{array}$ & $\begin{array}{l}0.1- \\
0.15\end{array}$ & $\begin{array}{l}0.1- \\
0.12\end{array}$ & $\begin{array}{c}0.09- \\
0.12\end{array}$ & $\begin{array}{c}0.09- \\
0.11\end{array}$ & $\begin{array}{c}0.1- \\
0.13\end{array}$ & $\begin{array}{l}0.1- \\
0.12\end{array}$ & $\begin{array}{c}0.09- \\
0.11\end{array}$ & $\begin{array}{l}0.1- \\
0.12\end{array}$ \\
\hline
\end{tabular}




\begin{tabular}{|c|c|c|c|c|c|c|c|c|c|}
\hline & $\begin{array}{l}\text { Length of } \\
\text { the part of } \\
\text { descending } \\
\text { arm } \\
\text { additionally } \\
\text { curved } \\
\text { upwards }\end{array}$ & $\begin{array}{c}0.18- \\
0.3\end{array}$ & $\begin{array}{c}0.13- \\
0.18\end{array}$ & $\begin{array}{c}0.14 \\
-0.17\end{array}$ & $\begin{array}{l}0.1- \\
0.11\end{array}$ & $\begin{array}{c}0.16- \\
0.2\end{array}$ & $\begin{array}{c}0.16- \\
0.17\end{array}$ & $\begin{array}{c}0.09- \\
0.15\end{array}$ & $\begin{array}{c}0.15- \\
0.18\end{array}$ \\
\hline 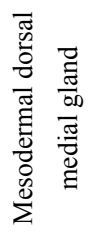 & Diameter & $\begin{array}{c}0.04 x \\
0.02\end{array}$ & $\begin{array}{c}0.04 x \\
0.01\end{array}$ & - & - & $\begin{array}{c}0.04 x \\
0.02\end{array}$ & - & $\begin{array}{c}0.04 x \\
0.01\end{array}$ & $\begin{array}{c}0.04 \mathrm{x} \\
0.02\end{array}$ \\
\hline 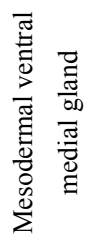 & Diameter & $\begin{array}{c}0.05 x \\
0.06\end{array}$ & $\begin{array}{c}0.03 x \\
0.04\end{array}$ & - & - & $\begin{array}{c}0.05 x \\
0.06\end{array}$ & - & $\begin{array}{c}0.03 x \\
0.04\end{array}$ & $\begin{array}{c}0.05 \mathrm{x} \\
0.06\end{array}$ \\
\hline \multirow{2}{*}{ 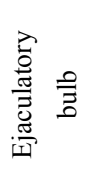 } & Length & 0.25 & 0.22 & 0.23 & 0.22 & 0.23 & 0.24 & 0.23 & 0.2 \\
\hline & Width & 0.26 & 0.24 & 0.24 & 0.24 & 0.22 & 0.23 & 0.24 & 0.21 \\
\hline
\end{tabular}

The whole reproductive system is contained in the genital capsule.

The testes are situated on the sides, outside the lateral glands. They consist of testicular follicles, which are internally divided into three regions, according to the development of the germ cells.

The three testicular follicles are identical in all species (Figs 3-7). The wall of each follicle is derived from peritoneal epithelium. Each follicle tapers in its basal part to form a short vas efferens. The vasa efferentia of all the testicular follicles of the same testis lead into the widened part of the vas deferens. The follicles are elongate and run rosette-like into the vas deferens, which leads out of the middle part of the testis. Although the individual follicles are appressed, they are never joined. All the follicles are enclosed in a common peritoneal membrane.

The peritoneal membrane is thin and translucent: the follicles can be seen through it. The borders between individual follicles are clearly visible in the external view. 
The independently running vasa deferentia expand in the proximal part to form seminal vesicles, providing a protective space for mature spermatozoa. The diameter of this part of the vas deferens varies, depending on the physiological state of the insect. The vasa deferentia of newly moulted adult males are always straight and the seminal vesicles are invisible. In the distal part the vasa deferentia expand, forming seminal vesicles (Fig. 10).

The distal seminal reservoirs are interconnected to form the common vas deferens, i.e. the so-called seminal duct (Figs 11-12) opening into the ejaculatory bulb.

Great diversity is typical of the genus Psallus as far as the number and kind of accessory glands are concerned. Within the accessory glands there are two single mesodermal glands and two pairs of ectodermal ones.

The ectodermal accessory glands are of a considerable size and constitute the largest part of the reproductive system of this species (Figs 1-2, 8-13). They are described below in detail.

The pair of external lateral glands: their size varies and depends on the age and the physiological condition of the insect. In freshly eclosed specimens they are rather small and empty. These glands are never divided into a number of separate parts. They run along the longitudinal axis of the body, and their proximal parts, bent at an acute angle, point towards the end of the abdomen. Thus, their ascending and descending arms can be distinguished. The descending arm of the gland is additionally bent upwards, forming loops (Figs 1-2). The diameter of the descending arm is smaller than that of the ascending arm.

The pair of internal lateral glands: their length is less variable than that of the external glands. In the species analysed here, these glands are divided into 3 parts, a characteristic of the genus under investigation (Figs 1-2). The two external parts - proximal and distal - are rather short. The long middle part is bent, changing from an ascending arm into a descending one. Both glands open into the anterior lateral part of the ejaculatory bulb; the internal glands are positioned proximally in relation to the external glands (Fig. 13).

The glands, which are small in size and therefore become visible only after the preparation of the histological slides, are mesodermal glands (Fig. 13).

The ventral medial gland is situated between the internal lateral glands (Fig. 11).

The dorsal medial gland is located between the vasa deferentia at the point where they become fused (Fig. 12). It opens into the ejaculatory bulb in its frontal part, above the outlet of the joint vasa deferentia.

Over their entire length the vasa deferentia and accessory glands run independently and their endings open into the ejaculatory bulb. This is the terminal section of the male reproductive system and is formed by the ducts that open into it. The ducts opening into the ejaculatory reservoir constitute parts of its wall (Fig. 13). The bulb is connected with the seminal duct of the aedeagus. 

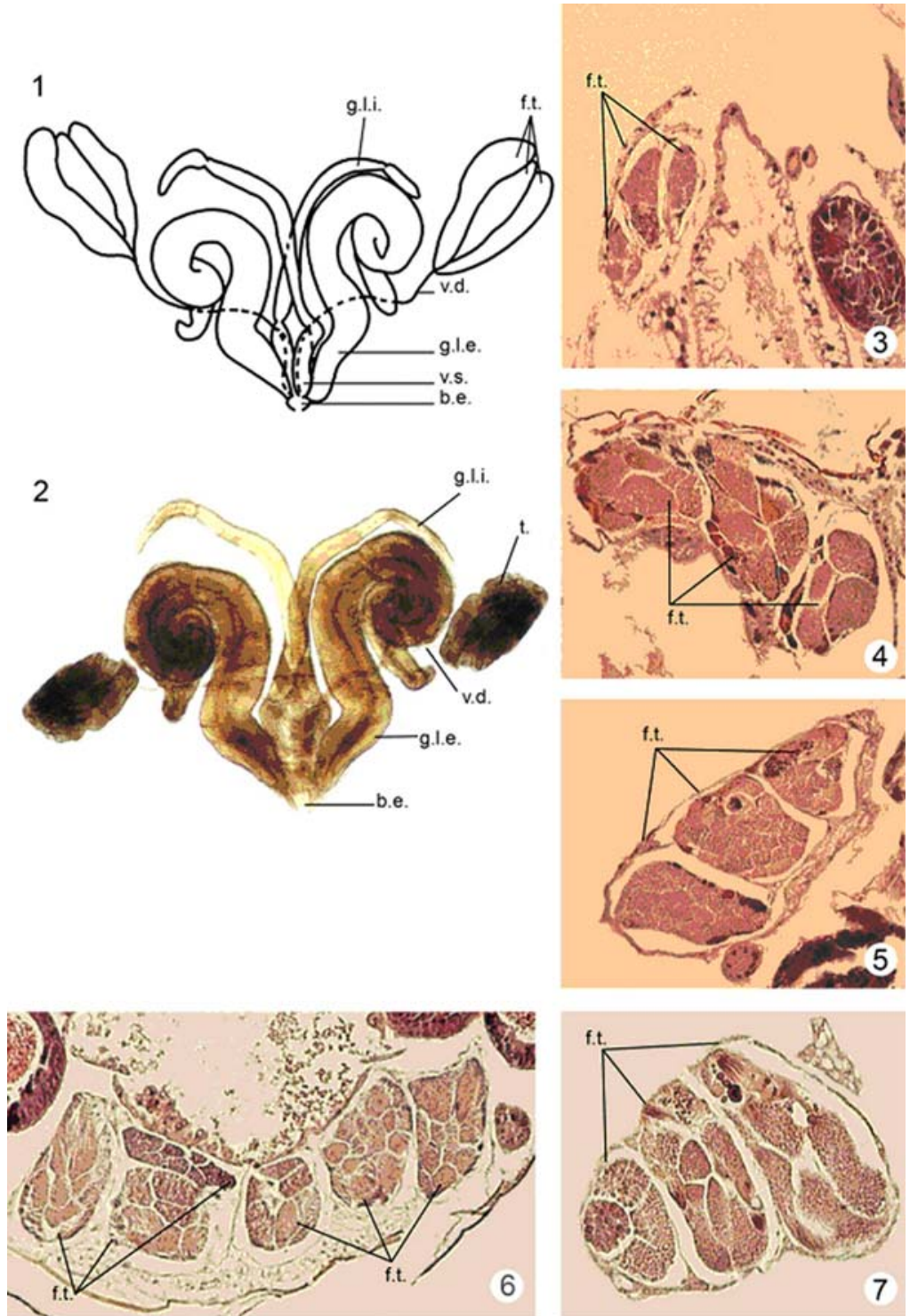

Figs 1-7. Male reproductive system of Psallus. 1-2. P. (H.) variabilis: 1 - Diagram of the male reproductive system, 2 - Total preparation, light microscopy (40x). 3-7. Fragments of cross-sections through the testis: $3-P$. (P.) falleni, $4-P$. (H.) variabilis, $5-P$. (M.) ambiguus, $6-P$. (A.) betuleti, $7-P$. (P.) vittatus. The testicular follicles (f.t.) making up the testis are visible. Haematoxylin + xylidine ponceau light microscopy $(100 \mathrm{x})$.

t. - testis, v.d. - vas deferens, v.s. - seminal vesicles, g.l.e. - external lateral gland, g.l.i. - internal lateral gland, b.e. - ejaculatory bulb. 

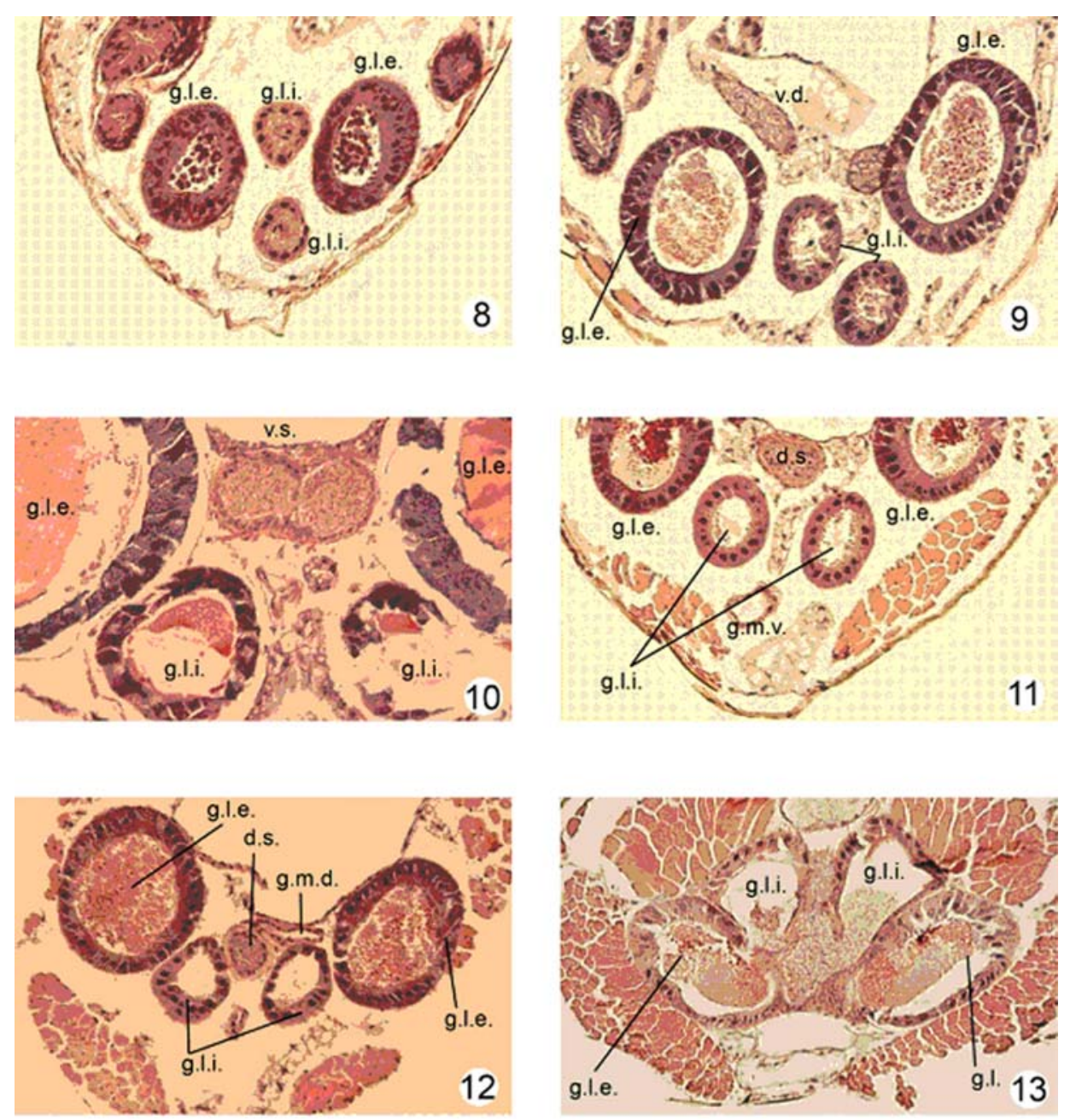

Figs 8-13. Fragments of cross-sections through the male reproductive system in some representatives of Psallus: 8 - P. (P.) falleni - fragment of cross-section through proximal part of ectodermal accessory glands (g.l.e., g.l.i.) (100x), 9 - P. (P.) falleni - fragment of cross-section through proximal part of vasa deferentia (v.d.) and ectodermal accessory glands (g.l.e., g.l.i.), (100x), 10-12 - P. (P.) falleni - fragment of cross-section through distal part of vasa deferentia (v.d.) and accessory glands (g.l.e., g.l.i., g.m.d., g.m.v.). Cross-section of seminal vesicles (v.s.) visible (100x), $13-P$. (P.) vittatus - cross-section through male reproductive system at the point where the distal parts of the system come together to form the walls of the ejaculatory bulb (b.e.) (100x).

v.d. - vas deferens, v.s. - seminal vesicles, d.s. - seminal duct, g.l.e. - external lateral gland, g.l.i. internal lateral gland, g.m.d. - dorsal medial gland, g.m.v. - ventral medial gland, b.e. - ejaculatory bulb. Haematoxylin + xylidine ponceau, light microscopy. 


\section{DISCUSSION}

The whole male reproductive system of the Psallus species analysed here is included in the genital capsule. In contrast, in many other studied species, e.g. Leptopterna dolabrata (LinNaeus, 1758), Adelphocoris lineolatus (GoEZE, 1778) and Phytocoris ulmi (LinNAEUS, 1758 ) it is much longer and extends to the first abdominal segments (BONHAG \& WICK 1953, KullenberG 1947, Mróz 2007, Mróz \& WoJCIECHOWSKi 2011).

The testes are located on the outside of the external lateral glands, as in species belonging to such genera as Adelphocoris (MASNER 1965) and Callocoris (MRÓz 2007), but unlike Oncopelthus (BonHAg \& Wick 1953), Phytocoris (Kullenberg 1947), Stenodema, Leptopterna and Notostira (MrÓz 2007, MRÓZ \& WOJCIECHOWSKI 2011), where the testes are located above the ectodermal glands.

The vasa deferentia, running independently in their proximal part, expand to form seminal vesicles, as in the species of the Stenodemini and Mirini tribes already described (Kullenberg 1947, MASNer 1965, Mróz 2007, Mróz \& WoJciechowsKi 2011).

Two pairs of ectodermal glands of a considerable size, constituting the main part of the reproductive system, together with two small mesodermal glands, were observed in the Psallus species studied here, as in other representatives of Miridae (KULLENBERG 1947, MASNER 1965).

Two pairs of ectodermal glands were found in these Psallus species, as in other representatives of Miridae (KULlENBERG 1947, MASNER 1965). These glands are large and make up the main part of the reproductive system. Two smaller mesodermal glands were also observed.

The internal ectodermal glands have a very characteristic morphology, as they are divided into three distinctive parts. The first and third parts are relatively short. In comparison to other representatives of the Miridae family, these glands may be uniform, as in Notostira (MRÓz 2007, MRÓz \& WOJCIECHOWSKI 2011), or clearly subdivided into two parts, as in Adelphocoris (MASNER 1965), Phytocoris (KULLENBERG 1947) or Trigonotylus (Mróz 2007, Mróz \& WoJCIECHOWSKI 2011). Within the genus Psallus the proximal parts of the internal glands are situated above the external glands.

It can be inferred from the results that the morphology of the male reproductive system in the genus Psallus has a uniform set of characteristics and that there are similarities among the species of this genus. The differences concern mainly the placement of individual elements, which ensues from the shape of the abdomen. Therefore, for example, the elements of the reproductive system of Psallus falleni are slimmer than their counterparts in that of Psallus ambiguus, which extend farther to the sides.

No essential differences have been observed in the morphology of this system among species belonging to different subgenera within the genus Psallus, but there are significant 
differences in the structure of the male reproductive system in the genus Stenodema, which corresponds to the division of this taxon into two subgenera (MRÓz 2007, MRÓz \& WOJCIECHOWSKI 2011).

All the species analysed have the same number of testicular follicles, identically built accessory glands, as well as very characteristic internal lateral glands. The results of this analysis confirm that the inclusion of all the species analysed here in the same genus is justified. However, the anatomical structure of the male reproductive system cannot serve to resolve problems concerning the taxonomic status of subgenera within the genus Psallus.

\section{REFERENCES}

Akingbohungbe A.E. 1983. Variation in testis follicle number in the Miridae (Hemiptera, Heteroptera) and its relationship to the higher classification of the family. Annals of the Entomological Society of America 76: 37-43.

BAGIŃSKI S. 1969. Technika mikroskopowa. PWN, Warszawa, 730 pp.

BonHAG P.F., Wick J.R. 1953. The functional anatomy of the male and female reproductive systems of the milkweed-bug, Oncopeltus fasciatus (DALlas) (Heteroptera: Lygaeidae). Journal of Morphology 93(2): 117-230.

CARAYON J. 1950. Nombre et disposition des ovarioles dans les ovaries des Hemiptères Heteroptères. Bulletin du Museum D'Histoire Naturelle, Paris 21: 710-716.

GorCZYCA J. 2007. Plant bugs (Heteroptera: Miridae) of Poland. MIZZ, 216 pp.

Grozeva S., KuZnetsova V.G. 1992. The reproductive system of some bug families (Heteroptera, Pentatomorpha) [In:] Bennettová B., GelbiC I., Soldan T. (eds). Advances in regulation of insect reproduction. Institute of Entomology, Czech Academy of Sciences, pp.: 97-102.

Kerzhner I.M., Josifov M. 1999. Miridae HAhn, 1833. [In:] Aukema B., Rieger Ch. (eds). Catalogue of the Heteroptera of the Palaearctic Region. Vol. 3, Cimicomorpha II. Netherlands Entomological Society. Wageningen, $577 \mathrm{pp}$.

Kullenberg B. 1947. Über Morphologie und Funktion des Kopulationsapparats der Capsiden und Nabiden. Zoologiska Bidrag fran Uppsala 24: 217-418.

KUMAR R. 1967. Morphology of the reproductive and alimentary system of the Aradoidea (Hemiptera), with comments on relationship within the superfamily. Annals of the Entomological Society of America 60: 17-25.

LESTON D. 1961. Testis follicle number and the higher systematics of Miridae (Hemiptera: Heteroptera). Proceedings of the Zoological Society of London 137(1): 89-106.

MaLipatil M.B. 1978. Testis follicle and ovariole numbers in the Lygaeidae (Heteroptera). Entomologist's Monthly Magazine 113: 1352-1355.

Mróz E. 2007. Anatomical and molecular studies of Stenodema LAPORTE genus (Heteroptera: Miridae). Genus, Supplement 14: 77-81.

Mróz E., WojCIECHOWSKI W. 2011. The systematic position the tribe of Stenodemini (Heteroptera: Cimicomorpha: Miridae: Mirinae) in the light of the male internal reproductive system. Journal of Natural History 45(25-28): 1-26.

MASNER P. 1965. The structure function and the imaginal development of the male inner reproductive organs of Adelphocoris lineolatus (GOEZE) (Heteroptera: Miridae). Acta Entomologica Bohemoslovaca 62(4): 254-276. 
PendeRgRast J.G. 1957. Studies on the reproductive organs of the Heteroptera with a consideration of their bearing on classification. Transactions of the Royal Entomological Society of London 109(1): 1-63.

WOODWARD T.E. 1950. Ovariole and testis follicles numbers in the Heteroptera. Entomologist's Monthly Magazine 86: 82-84.

VinOKUROV N.N. 1998. Asian plant bugs of the subgenus Pityopsallus E. WaGn., genus Psallus FieB. (Heteroptera: Miridae). Zoosystematica Rossica 7(2): 285-296.

Yasunaga T., Vinokurov N.N. 2000. The Phyline plant bug genus Psallus Fieber in Japan (Heteroptera: Miridae: Phylinae). Entomological Science 3(4): 653-668.

Received: August 8, 2011

Accepted: April 16, 2012 